Reprod. Nutr. Dévelop., 1980, 20 (1 B), 251-259.

\title{
Development of Sertoli cell populations in organ culture of immature pig testis
}

\author{
par Michelle CHEVALIER, J. P. DUFAURE
}

Laboratoire de Biologie cellulaire ef génétique

Complexe scientifique des Cézeaux, BP 45, 63170 Aubière, France.

Summary. Small samples of porcine testis were maintained in organ culture (medium $199+10$ p. 100 calf serum) during 16 days with various gonadotropins (hCG, ovine LH, ovine or porcine FSH) or without hormones. Several structural and ultrastructural parameters were studied. Testosterone released into the medium was measured and expressed as $\mathrm{ng} / \mathrm{ml} / 48 \mathrm{hrs}$.

When no hormones were added, the testosterone increased from $1.5 \pm 0.2 \mathrm{ng}$ to $5.1 \pm 0.7 \mathrm{ng}$ between 3 and 12 days, then declined. Seminiferous cord diameter decreased. The Sertoli cell nuclei became round; the cytoplasm was unaffected until 8 days, then showed alterations.

With ovine $\mathrm{LH}(2.8 \mu \mathrm{g} / \mathrm{ml})$, testosterone increased dramatically to $32.3 \pm 8.6 \mathrm{ng}$ at 6 days, then fell to $3.3 \pm 0.7 \mathrm{ng}$ at 14 days. Seminiferous cord diameter and the shape of the nuclei were like those of the controls. At 14 days, Sertoli cell cytoplasm showed a paucity of ER, ribosomes and microfilaments. At about 14 days, dark cells, similar to adult $B$ cells, appeared.

With ovine or porcine FSH $(2.8 \mu \mathrm{g} / \mathrm{ml})$, a constant rate of testosterone was maintained $(12.2+2.8 \mathrm{ng}$ at 14 days with porcine FSH). Seminiferous cord diameter was unaltered. Sertoli cell nuclei were elongated. At 14 days, ribosomes, ER and microfilaments were very abundant. The latter were organized into Charcot-Böttcher crystalloids.

When both gonadotropins were given simultaneously $(1.4 \mu \mathrm{g}$ of ovine LH per $\mathrm{ml}+1.4 \mu \mathrm{g}$ of ovine FSH per $\mathrm{ml})$ or with hCG $(4 \mu \mathrm{g} / \mathrm{ml})$, the main positive effects were combined : proliferation of $E R$, ribosomes and microfilaments, and the appearance of a second type of cell.

Cellular dimorphism seemed to be directly or indirectly controlled by LH-like hormones, whereas the abundance of ER, ribosomes and microfilaments appeared to be controlled by FSH or (and) testosterone.

\section{Introduction.}

FSH control of the Sertoli cell was demonstrated by Murphy $(1965 a, b)$. Since then, many studies have proved that this cell in the testis is the FSH target cell (Steinberger and Steinberger, 1977 ; Means, 1977 ; Hansson et al., 1978). Testosterone action on the Sertoli cell has also been shown (Means et al., 1976 ; Hansson et al., 1978). Research on hypophysectomized animals (Weddington et al., 1975 ; Elkington ef al., 1975, 1977) suggests that FSH and testosterone effects are correlated in the production of androgen binding protein (ABP) (Means, 1977 ; Hansson et al., 1978). The culture of samples of 
testicular seminiferous tubules or of isolated Sertoli cells has confirmed all the results obtained so far (Hansson et al., 1978).

The Sertoli cell has been studied in different physiological conditions, i.e. immature, pubescent, adult, cryptochidic and hypophysectomized boars (Chevalier, 1978, 1979). It was shown that after puberty the Sertoli cell population was heterogeneous (A and $B$ cells), and that cellular dimorphism was maintained in animals in which the sexual functions were disturbed or suppressed (cryptorchidism, hypophysectomy). In typical A cells, some organelles (endoplasmic reticulum, microfilaments, microtubules) were modified according to the physiological conditions.

In the present study, we wished to determine the factors controlling Sertoli cell dimorphism and maturation during postnatal development. Samples from the testes of 6-week old piglets were cultured for 16 days with different gonadotropins. The results are discussed in relation to the type of hormone used and the amount of testosterone released in the culture medium. $U_{P}$ to now, ultrastructural changes in the immature Sertoli cell in in vitro conditions have been mainly studied in the rat (Tung et al., 1975a, b ; Bigliardi and Vegni-Talluri, 1976 ; Solari and Fritz, 1978 ; Fritz et al., 1978 ; Meyer ef al., 1978).

\section{Material and methods.}

The experiments were carried out using 6-week old domesticated Large-White pigs (Sus scrofa L.). The organ culture technique has already been described (Morat ef al., 1971 ; Morat, 1977). Pituitary LHovine NIH-S20 (1.19 units of NIH-LH-S1/mg, contaminated with less than 0.05 units of $\mathrm{NIH}-\mathrm{FSH}-\mathrm{S1} / \mathrm{mg}$ ), $\mathrm{FSH}_{\text {ovine }} \mathrm{NIH}-\mathrm{S} 12$ (1.25 units of $\mathrm{NIH}-\mathrm{FSH}-\mathrm{S} 1 / \mathrm{mg}$, contaminated with less than 0.01 units of $\mathrm{NIH}-\mathrm{LH}-\mathrm{S} 1 / \mathrm{mg}$ ) or $\mathrm{FSH}_{\text {porcine }} \mathrm{NIH}-\mathrm{P} 2(0.69$ units of NIH-FSH-S1/mg, contaminated with less than 0.01 units of $\mathrm{NIH}-\mathrm{LH}-\mathrm{S} 1 / \mathrm{mg}$ ) were added to the medium at a final concentration of $2.8 \mu \mathrm{g} / \mathrm{ml}$ for about $5 \mathrm{mg}$ of tissue. Equal parts of these hormones were used when the two were combined together, the final concentration remaining unchanged. $4 \mu \mathrm{g}$ of human chorionic hormone (hCG) (Organon), titrated at $3000 \mathrm{IU} / \mathrm{mg}$, were dissolved in $1 \mathrm{ml}$ of medium. The control cultures contained no added hormones. The medium used was 199 medium with Hank's salts (Institut Pasteur) with 10 p. 100 calf serum added (Institut Pasteur).

Histological and ultrastructural studies were carried out on testicular samples from 2 animals; the techniques have been described previously (Chevalier, 1979). The testicular parameters, such as seminiferous cord (SC) diameter, number of Sertoli cells per cross-section of seminiferous cord, elongation of Sertoli cell nuclei and Leydig cell diameter were determined from photographs $(\times 400)$. Each figure corresponded to the mean of 10 measurements, followed by the standard error. The number of Sertoli cells per microtome section of seminiferous cord corresponded to the mean number observed corrected with Abercrombie's formula (1946), followed by the standard error.

Elongation of the Sertoli cell nuclei was defined by the ratio $D / d$, where $D$ was the large diameter and $d$ the small one.

The testosterone levels were determined in the medium of 3 culture series, each series corresponding to one animal. We used the RIA technique of Veyssière et al. (1975) without celite column chromatography, previous assays having shown that DHT 
level was low (at most, 5 p. 100 of the testosterone level). The linear correlation between the quantity of hormone measured and the volume of the medium extracted was significant $(r=0.991 ; P<0.001)$.

The number of measurements for each mean was indicated by the value of $n$. Results were statistically analyzed using Student's t-test.

\section{Results.}

Histological study. - The values of the parameters chosen to characterize the development of testicular tissue, in relation to culture time-course and different hormonal conditions, are shown in table 1.

\section{TABLE 1}

Effects of different gonadotropic hormones on testicular fissue in organ culture

\begin{tabular}{|c|c|c|c|c|c|c|}
\hline $\begin{array}{l}\text { Culture } \\
\text { time-course }\end{array}$ & $\begin{array}{c}\text { SC diameter } \\
(\text { in } \mu \mathrm{m}) \\
n==10\end{array}$ & $\begin{array}{l}\text { No. of Sertoli } \\
\text { cells per SC } \\
\text { section, } n=10\end{array}$ & $\begin{array}{c}D / d \text { of Sertoli } \\
\text { cell nuclei } \\
n=10\end{array}$ & $\begin{array}{c}\text { Leydig cell } \\
\text { diameter } \\
\text { (in } \mu \mathrm{m}) \mathrm{n}=10\end{array}$ & \multicolumn{2}{|c|}{$\begin{array}{l}\text { Testosterone } \\
\text { released } / \mathrm{ml} \text { of } \\
\text { medium in } 48 \mathrm{hrs} \\
\text { (in } \mathrm{ng} \text { ) }\end{array}$} \\
\hline Before culture & $49.6 \pm 1.64$ & $12.28 \pm 0.60$ & $1.92 \pm 0.05$ & $16.12 \pm 0.39$ & & \\
\hline $\begin{array}{l}\text { Control } \\
\text { 3d }{ }_{0}^{0} \text { FSH } \\
{ }_{0}^{\mathrm{LH}} \mathrm{FSH} \\
\text { hCG } \\
\text { hCG }\end{array}$ & $\begin{array}{l}46.6 \pm 0.85 \\
49.6 \pm 1.55 \\
51.6 \pm 1.23 \\
48.2 \pm 1.26 \\
53.2 \pm 1.17 \\
45.4 \pm 0.85\end{array}$ & $\begin{array}{l}13.36 \pm 0.84 \\
12.31 \pm 0.61 \\
12.96 \pm 0.71 \\
12.12 \pm 0.69 \\
12.48 \pm 0.56 \\
13.30 \pm 0.65\end{array}$ & $\begin{array}{l}1.52 \pm 0.06 * \\
1.36 \pm 0.05^{*} \\
1.49 \pm 0.06 * \\
1.75 \pm 0.08 \\
1.61 \pm 0.11 \\
1.50 \pm 0.05 *\end{array}$ & $\begin{array}{l}14.25 \pm 0.58 \\
14.77 \pm 0.61 \\
13.60 \pm 0.60 \\
14.67 \pm 0.55 \\
14.67 \pm 0.57 \\
14.84 \pm 0.43\end{array}$ & $\begin{array}{c}1.5 \pm 0.2 \\
7.8 \pm 0.9^{* *} \\
3.0 \pm 0.5 \\
12.5 \pm 0.9^{* *}\end{array}$ & $\begin{array}{l}n=4 \\
n=4 \\
n=3 \\
n=4\end{array}$ \\
\hline 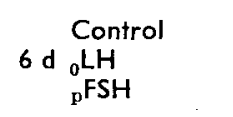 & & & & & $\begin{array}{c}2.8 \pm 0.2 \\
32.3 \pm 8.6 * * \\
20.3 \pm 5.3^{* *}\end{array}$ & $\begin{array}{l}n=4 \\
n=4 \\
n=4\end{array}$ \\
\hline 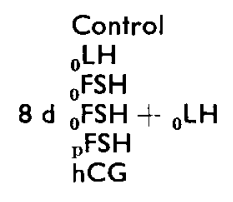 & $\begin{array}{l}47.4 \pm 1.04 \\
45.2 \pm 1.20 \\
52.0 \pm 1.97 \\
51.8 \pm 0.81 \\
50.6 \pm 1.30 \\
47.8 \pm 1.01\end{array}$ & $\begin{array}{l}13.87 \pm 0.66 \\
13.44 \pm 0.53 \\
14.80 \pm 0.87 \\
13.53 \pm 0.48 \\
14.44 \pm 0.54 \\
13.15 \pm 0.72\end{array}$ & $\begin{array}{l}1.49 \pm 0.13^{*} \\
1.41 \pm 0.07 * \\
1.77 \pm 0.07 \\
1.90 \pm 0.12 \\
1.75 \pm 0.11 \\
1.57 \pm 0.10\end{array}$ & $\begin{array}{l}12.42 \pm 0.39 \\
13.37 \pm 0.46 \\
12.71 \pm 0.30 \\
14.12 \pm 0.59 \\
13.00 \pm 0.25 \\
14.58 \pm 0.43\end{array}$ & $\begin{array}{c}3.7 \pm 0.8 \\
19.9 \pm 3.3^{* *} \\
8.6 \pm 0.5^{* *} \\
16.2 \pm 4.9^{* *}\end{array}$ & $\begin{array}{l}n=4 \\
n=3 \\
n=3 \\
n=4\end{array}$ \\
\hline $\begin{array}{l}\text { Control } \\
10 \mathrm{~d}{ }_{0}^{0} \mathrm{LH} \\
12 \mathrm{~d} \\
{ }_{0} \mathrm{FSH} \\
{ }_{\mathrm{p}}^{\mathrm{FSHH}}+{ }_{\mathrm{h}} \mathrm{FSH} \\
\mathrm{hCG}\end{array}$ & $\begin{array}{l}43.4 \pm 1.46 * \\
43.4 \pm 0.99 * \\
49.6 \pm 1.15 \\
51.2 \pm 0.99 \\
51.4 \pm 0.79 \\
48.6 \pm 1.07\end{array}$ & $\begin{array}{l}15.08 \pm 0.90 \\
15.26 \pm 0.71 \\
17.77 \pm 0.91 \\
15.46 \pm 0.65 \\
17.15 \pm 0.55 \\
15.02 \pm 0.47\end{array}$ & $\begin{array}{l}1.49 \pm 0.08 * \\
1.62 \pm 0.13 \\
1.73 \pm 0.14 \\
1.85 \pm 0.07 \\
2.16 \pm 0.15 \\
1.66 \pm 0.08 *\end{array}$ & $\begin{array}{l}12.00 \pm 0.37 \\
12.96 \pm 0.30 \\
12.88 \pm 0.48 \\
14.09 \pm 0.45 \\
13.71 \pm 0.40 \\
14.21 \pm 0.52\end{array}$ & $\begin{aligned} 5.1 & \pm 0.7 \\
4.8 & \pm 0.5 \\
15.9 & \pm 1.3 * * \\
13.9 & \pm 2.8 * *\end{aligned}$ & $\begin{array}{l}n=9 \\
n=10 \\
n=3 \\
n=8\end{array}$ \\
\hline $\begin{array}{l}\text { Control } \\
14 d{ }_{0}{ }_{0}^{\mathrm{LH}} \\
16 \mathrm{FSH} \\
{ }_{0} \mathrm{FSH}+{ }_{0} \mathrm{LH} \\
{ }_{\mathrm{p}} \mathrm{FSH} \\
\mathrm{hCG}\end{array}$ & $\begin{array}{l}45.0 \pm 0.61 * \\
41.6 \pm 1.10 * \\
48.8 \pm 1.12 \\
52.4 \pm 1.02 \\
52.2 \pm 0.75 \\
53.4 \pm 1.49\end{array}$ & $\begin{array}{l}16.28 \pm 0.43 \\
17.42 \pm 0.29 \\
16.98 \pm 0.82 \\
18.07 \pm 0.48 \\
16.52 \pm 0.57 \\
15.48 \pm 0.43\end{array}$ & $\begin{array}{l}1.49 \pm 0.11^{*} \\
1.56 \pm 0.07^{*} \\
1.66 \pm 0.05^{*} \\
1.90 \pm 0.06 \\
2.19 \pm 0.12 \\
1.84 \pm 0.07\end{array}$ & $\begin{array}{l}10.12 \pm 0.32 \\
11.87 \pm 0.28 \\
11.87 \pm 0.28 \\
12.29 \pm 0.25 \\
13.46 \pm 0.39 \\
14.09 \pm 0.31\end{array}$ & $\begin{array}{c}1.3 \pm 0.5 \\
3.3 \pm 0.7 \\
10.0 \pm 0.9 * * \\
12.2 \pm 2.8^{* *}\end{array}$ & $\begin{array}{l}n=4 \\
n=6 \\
n=3 \\
n=6\end{array}$ \\
\hline
\end{tabular}

SC : seminiferous cord ; $\mathrm{D} / \mathrm{d}$ : ratio of large diameter (D) to small diameter (d) of Sertoli cell nuclei ; $n$ : number of measurements.

Testosterone was assayed in medium kept in the presence of the organ culture for $48 \mathrm{hrs}$.

Significantly different from the normal before culture $*: \mathrm{P}<0.1 ;{ }^{*}: \mathrm{P}<0.05$.

Significantly different from the control $* *: P<0.05$. 
In no case did the cellular content of the seminiferous cord epithelium show significant changes. The epithelium was composed of many juxtaposed Sertoli cells and some germ cells. When no gonadotropic hormones were present, seminiferous cord diameter decreased and Sertoli cell nuclei became round (fig. 1). In cultures containing only LH, the results were identical to those of the controls (fig. 1). On the other hand, the seminiferous cords had the same diameter, and Sertoli cell nuclei were elongated when the medium contained testosterone + FSH (fig. 1). Few mitotic figures were seen, and thus approximately the same number of Sertoli cells was maintained. In no case, did the seminiferous cords acquire a lumen. It may be concluded that variations in the diameter of the seminiferous cords expressed variations in Sertoli cell volume.

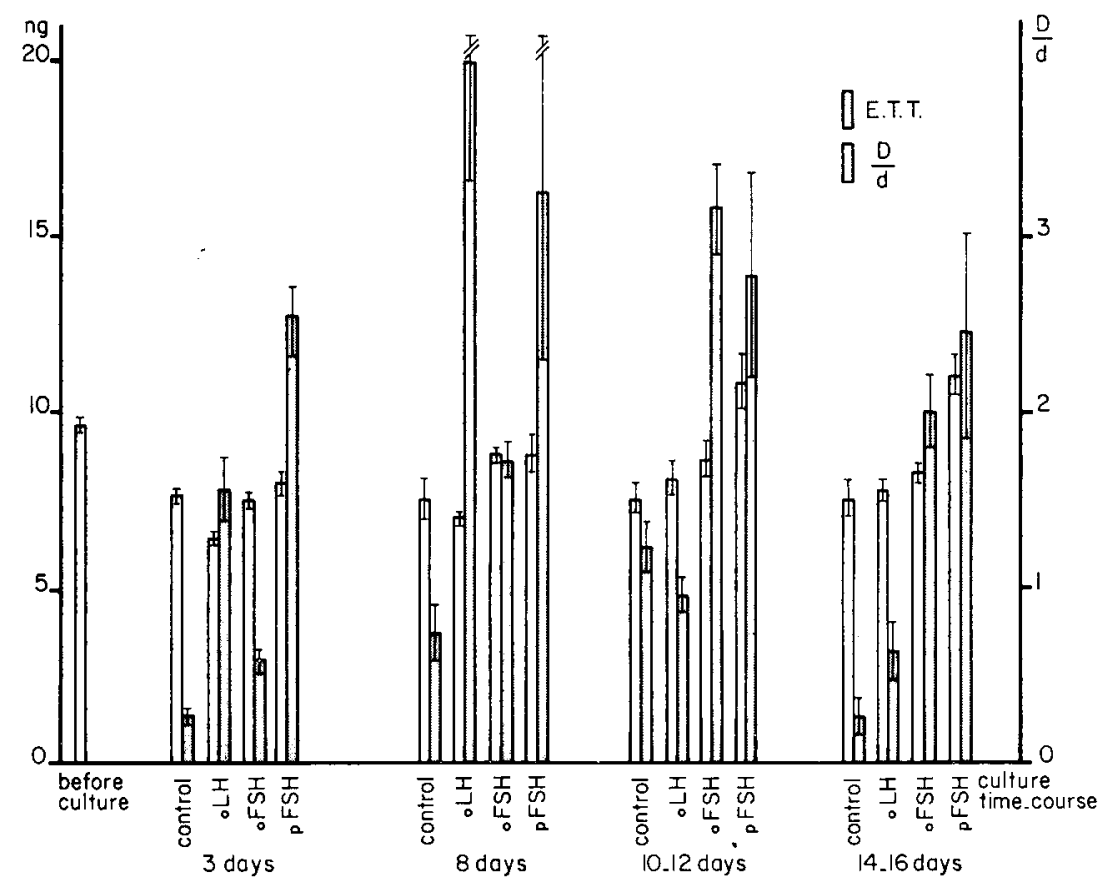

FIG. 1. - Variations in the form of Sertoli cell nuclei according to (i) the type of pituitory hormone and the amount of testosterone present in the medium, and (ii) culture time-course. Sertoli cell nuclei become round without gonadotropic hormones or in the presence of $\mathrm{LH}$ alone. Testosterone levels correspond to the amount of hormone released per $\mathrm{ml}$ of medium in $48 \mathrm{hrs}$. ETT = extra-tissular test. $\mathrm{D} / \mathrm{d}$ : ratio of large diameter (D) to small diameter (d) of Sertoli cell nuclei.

Ultrastructural study. - Except for the disappearance of some interchromatin granules, Sertoli cell nuclei in all cases had about the same structure as that described in vivo in the immature. The nuclei were accompanied by a voluminous lipid droplet characteristic of porcine Sertoli cells. The mitochondria were little affected. The Golgi apparatus was well developed ; in the presence of FSH it was surrounded by a considerable number of vesicles. The Sertoli cell junctions showed no structural development. 
As concerned other cellular components, large differences appeared, depending on the culture time-course and the hormonal composition of the medium.

Control culture. - In the first days, there was little cellular transformation. Then the endoplasmic reticulum (ER), ribosomes and microfilaments regressed. From day 12 on, many lipid droplets, lysosomes and myelinic figures were formed.

Culture with $L H$. - No cell showed any sign of degeneration. At first, the ER and the ribosomes remained dense, then they gradually became less so. The microfilaments disappeared. Towards day 14, the Sertoli cell population was composed of two cell types (fig. 2). The new cells were smaller and darker than the others, and showed no signs of necrosis. They resembled adult B cells. This process was limited to a small number of cells.

Culture with FSH. - The observations in the presence of ovine or porcine FSH were identical. The ER proliferated, at first appearing as groups of small saccules arranged in large concentric circles (fig. 3), as in vivo in the immature ; later, it was found more often in its smooth form distributed throughout the cytoplasm. Ribosomes were very abundant (fig. 3). The microfilaments, after first proliferating to the periphery of the nucleus, might then form patterns in other cytoplasmic areas, identical to adult Charcot-Böttcher crystalloids (fig. 4).

Culfure with hCG or with $L H+F S H$. - The ER and the ribosomes developed very quickly and were abundant. The saccules of ER were distributed as in the preceding case, and their development was the same. Towards day 14, a second cell type formed which was identical to the type obtained with $\mathrm{LH}$. The number of microfilaments decreased, then augmented in the presence of hCG. In cultures containing LH $+\mathrm{FSH}$, the microfilaments first remained dense, then proliferated considerably in the perinuclear region (fig. 5).

\section{Discussion.}

Sertoli cells are under FSH and androgen control (Hansson et al., 1978). Gonadotropins may thus act on these cells either directly (FSH effect) or indirectly by testosterone mediation ( $\mathrm{LH}$ effect). The tissues used in this study were sampled at a time when the levels of plasma LH and testosterone were lowest (FlorCruz and Lapwood, 1978). In our experimental conditions, LH caused a rapid increment of the level of testosterone released into the medium, then a decrease of that level. This might be due to a process of desensitization after overstimulation of the Leydig cells (Hsueh et al., 1976). With FSH, the quantity of testosterone reached levels which could be 2 to 6 times higher than those obtained in the control cultures. This secretion might result from stimulation of the Leydig cells by the small a mount of $\mathrm{LH}$ contaminating the FSH. It should be noted that, even though no gonadotropins were added, the control cultures released a fair amount of testosterone. This product could be related to the presence of calf serum which could contain steroid or polypeptidic hormones.

This study shows that, in the immature pig. FSH or testosterone is necessary for maintaining the volume of the Sertoli cells and for their maturation (development of 


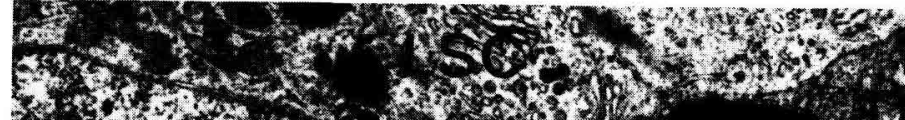

S.6.

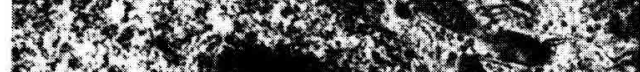

6.5.

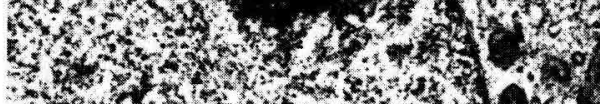

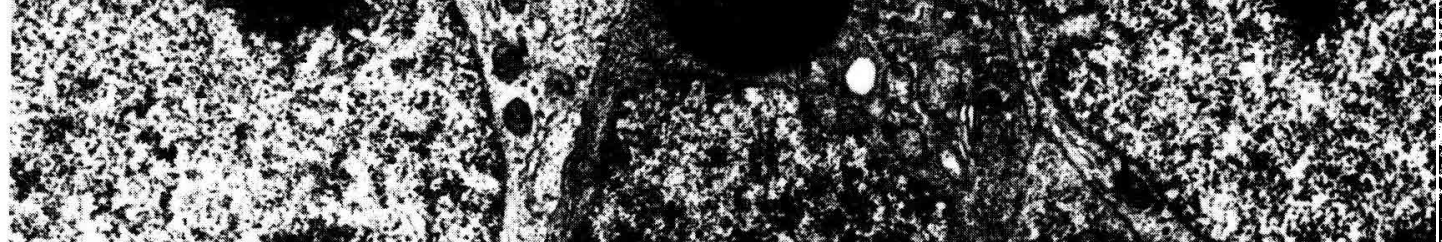

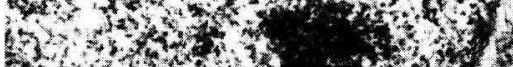

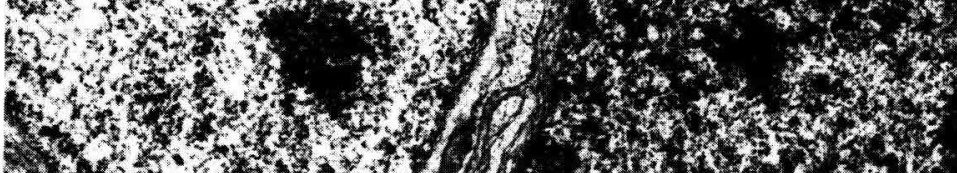

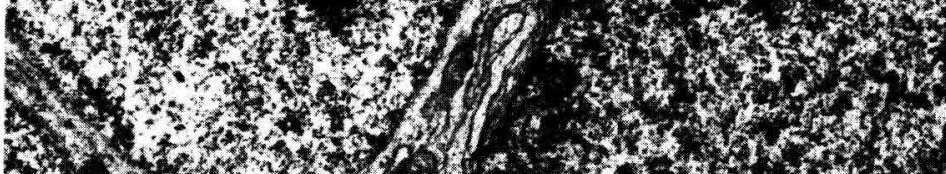

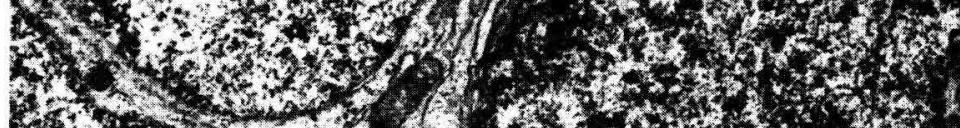

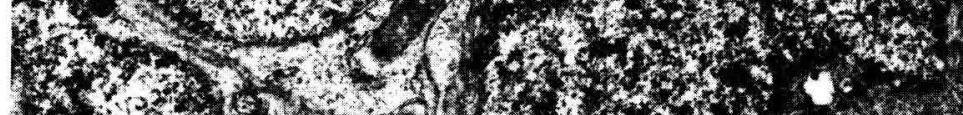

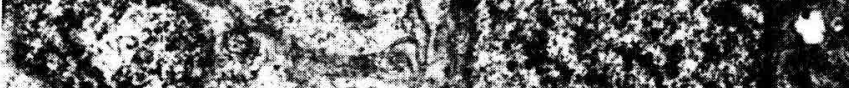

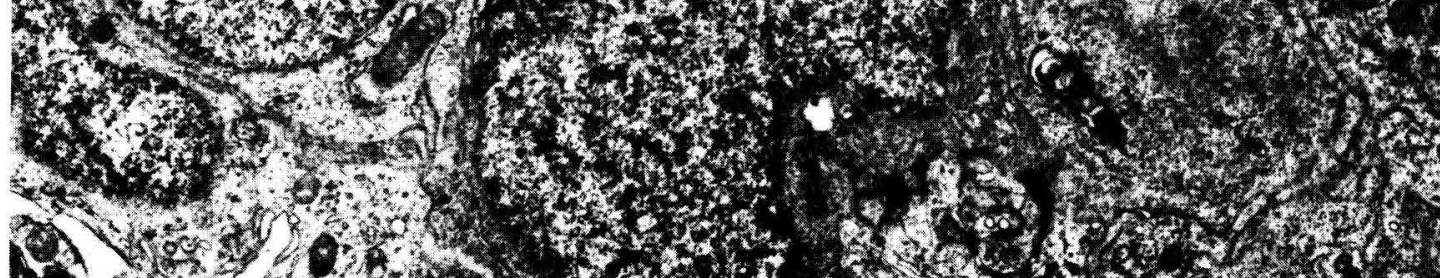

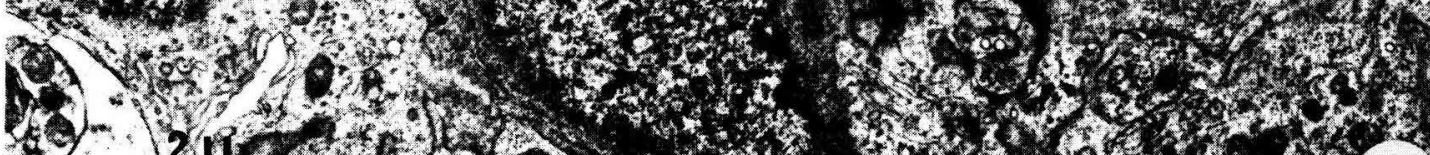

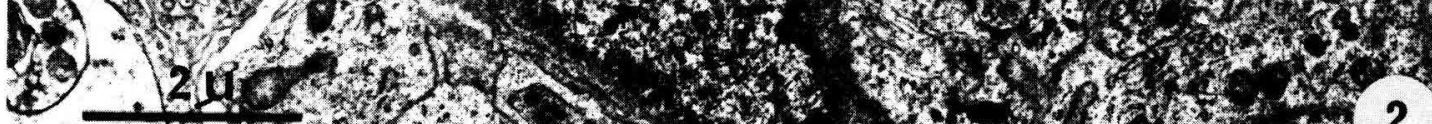

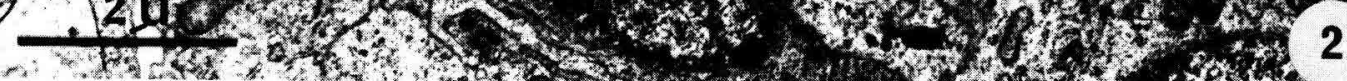

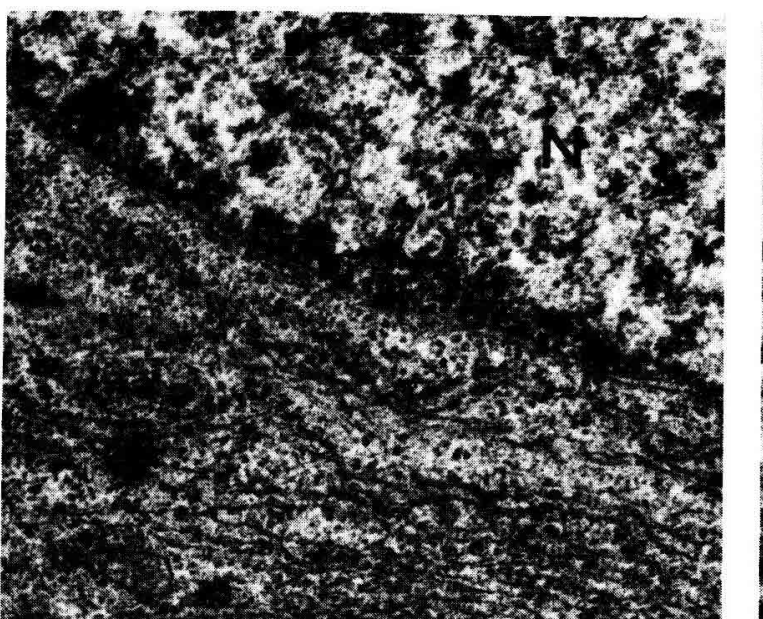
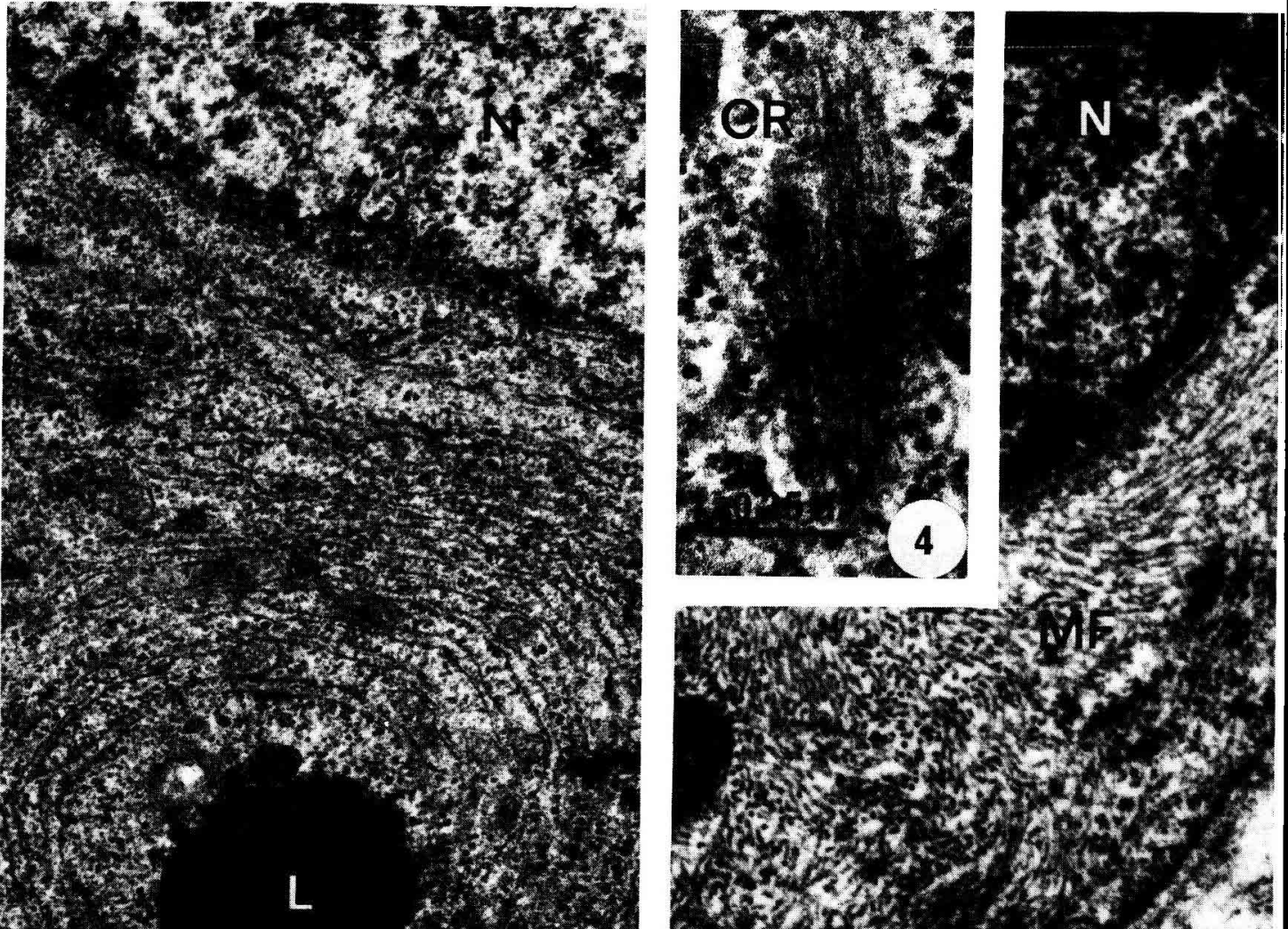

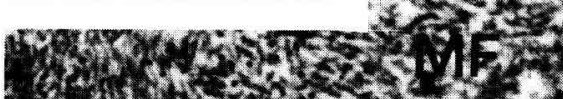

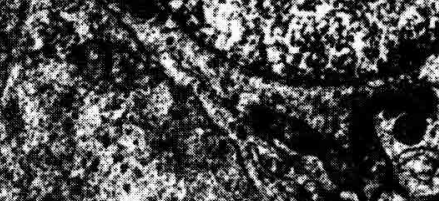

X.2.

7to

$-7$

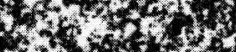

swy 
the ER and microfilaments). Using ultrastructural or functional criteria (ABP secretion), the same conclusions were drawn for the immature rat (Cameron and Markwald, 1975 ; Tung ef al., 1975a, b ; Meyer ef al., 1978 ; Solari and Fritz, 1978 ; Kotite ef al., 1978; Chemes et al., 1979). The synergic action of testosterone in the presence of FSH cannot be excluded in our experimental conditions.

From our observations in vitro on the immature pig, the appearance of the second Sertoli cell type would result directly or indirectly (mediated by an androgen) from LH action. In the normal animal, cell dimorphism has been found beginning at prepuberty (Wrobel and Dierichs, 1975). It would thus be established at a time when the levels of plasma LH and testosterone are particularly high (FlorCruz and Lapwood, 1978). These conclusions have not been confirmed by in vivo studies on humans (Johnsen, 1969 ; Wartenberg. 1978) or hypophysectomized lambs (Courot, 1971) or by in vitro studies on the rat (de Martino ef al., 1977 ; Solari and Fritz, 1978).

In conclusion, Sertoli cell maturation in the immature pig is controlled by FSH or (and) testosterone, while the appearance of cellular dimorphism would be $\mathrm{LH}$ dependent. Observations on hypophysectomized, pubescent animals (Chevalier, 1979) do not agree with our hypotheses, and indicate that after puberty, the controls may be different. It is necessary to obtain more precise data using isolated Sertoli cells cultured in the presence of testosterone, FSH or LH.

5e Réunion du groupe Développement I.N.R.A., Clermont-Ferrand/Theix, 17-18 mai 1979.

Résumé. Des fragments de testicule de porc de 6 semaines sont maintenus en culture (milieu $199+10$ p. 100 sérum de veau) pendant 16 jours en présence de différentes gonadotropines (hCG, LH ovine, FSH ovine et FSH porcine). Différents paramètres structuraux ef ultrastructuraux ont été étudiés ainsi que le taux de testostérone libérée en $48 \mathrm{~h}$ par $\mathrm{ml}$ de milieu.

- Cultures témoins. Le taux de testostérone passe de $1,5 \pm 0,2 \mathrm{ng}$ après 3 jours à $5,1 \pm 0,7 \mathrm{ng}$ après 12 jours puis décroît. Le diamètre des cordons séminifères diminue. Le noyau sertolien s'arrondit, le cytoplasme est peu affecté jusqu'au $8^{e}$ jour, au-delà, il présente des signes d'altération.

- Avec LH ovine $(2,8 \mu \mathrm{g} / \mathrm{ml})$, le taux de testostérone augmente rapidement jusqu'au $6^{\mathrm{e}}$ jour $(32,3 \pm 8,6 \mathrm{ng})$ puis décroît, il est de $3,3 \pm 0,7 \mathrm{ng}$ le $14^{\mathrm{e}}$ jour. Le diamètre des cordons séminifères et la forme des noyaux sertoliens évoluent comme chez les témoins. Au

Organ culfures of samples of 6-week pig festis : Sertoli cell ultrastructure. (CR : Charcot-Böttcher crystalloid ; LSC : light Sertoli cell ; DSC : dark Sertoli cell ; L : lipid ; MF : microfilaments ; $N$ : nucleus.)

FIG. 2. - After 14 days in the presence of ovine $L H$, the Sertoli cell population is composed of light Sertoli cells and dark Sertoli cells $(\times 11000)$.

FIG. 3. - After 7 days in the presence of porcine FSH, the ER and ribosomes proliferate $(\times 27000)$.

FIG. 4. - After 16 days in the presence of porcine FSH, the microfilaments form a Charcot-Böttcher crystalloid $(\times 65000)$.

FIG. 5. - After 16 days in the presence of ovine $L H+$ ovine $F S H$, the microfilaments are very abundant in the perinuclear region $(\times 39000)$. 
$14^{\mathrm{e}}$ jour, le cytoplasme des cellules de Sertoli renferme peu de RE, de ribosomes et de microfilaments. Des cellules sombres apparaissent : elles rappellent les cellules B de l'adulte. - Avec FSH ovine ou FSH porcine $(2,8 \mu \mathrm{g} / \mathrm{ml})$; le taux de testostérone se maintient à un taux assez constant $(12,2 \pm 2,8 \mathrm{ng}$ après 14 jours en présence de $\mathrm{FSH}$ porcine). Le diamètre des cordons séminifères ne change pas. Les noyaux sertoliens demeurent allongés. Après 14 jours, le cytoplasme des cellules de Sertoli renferme une grande quantité de RE lisse, de ribosomes, et de microfilaments. Ces derniers s'organisent pour former des cristalloïdes de Charcot-Böttcher.

- Avec LH ovine $(1,4 \mu \mathrm{g} / \mathrm{ml})+\mathrm{FSH}$ ovine $(1,4 \mu \mathrm{g} / \mathrm{ml})$ ou avec hCG $(4 \mu \mathrm{g} / \mathrm{ml})$. Le développement du RE et des ribosomes est très rapide. Il apparaît des cellules sombres. La multiplication des microfilaments est particulièrement évidente en présence des deux hormones hypophysaires.

Le dimorphisme cellulaire paraît (directement ou indirectement) soumis à un effet LH. L'abondance de RE, des ribosomes et des microfilaments serait plutôt sous le contrôle de FSH ou (ef) de la testostérone.

\section{Références}

ABERCROMBIE M., 1946. Estimation of nuclear population from microtome sections. Anat. Rec., 94, 239-247.

BIGLIARDI E., VEGNI-TALLURI M., 1976. Ultrastructural details of Sertoli cell junctional complexes in vivo and their modification in tissue culture. Cell Tissue Res., 172, 29-38.

CAMERON D., MARKWALD R. R., 1975. Histochemical and ultrastructural observations in normal and follicle stimulating hormone-injected prepuberal rat Sertoli cells, 479-493. In FRENCH F. S., HANSSON V., RITZEN E. M., NAYFEH S. N., Hormonal regulation of spermatogenesis. Plenum Press, New York.

CHEMES H. E., DYM M., RAJ H. G. M., 1979. Hormonal regulation of Sertoli cell differentiation. Biol. Reprod., 21, 251-262.

CHEVALIER M., 1978. Sertoli cell ultrastructure. I. A comparative study in immature, pubescent, adult and cryptorchid pigs. Ann. Biol. anim. Bioch. Biophys., 18, 1279-1292.

CHEVALIER M., 1979. Sertoli cell ultrastructure. Il. Morphological effects of hypophysectomy in pubescent pigs. Ann. Biol. anim. Bioch. Biophys., 19, 583-596.

COUROT M., 1971. Etablissement de la spermatogenèse chez l'agneau (ovis aries). Etude expérimentale de son contrôle gonadotrope : importance des cellules de la lignée sertolienne. Th. $\mathrm{D}^{\mathrm{r}}$ ès Sci. Paris, CNRS A. O. 6317.

ELKINGTON J. S. H., SANBORN B. M., STEINBERGER E., 1975. The effect of testosterone propionate on the concentration of testicular and epididymal androgen binding activity in the hypophysectomized rat. Molec. cell. Endocrinol., 2, 157-170.

ELKINGTON J. S. H., SANBORN B. M., MARTIN N. W., CHOWDHURY A. K., STEINBERGER E., 1977. Effect of testosterone propionate on ABP in rats hypophysectomized at different ages using individual sampling. Molec. cell. Endrocrinol., 6, 203-219.

FLORCRUZ S. V., LAPWOOD K. R., 1978. A longifudinal study of pubertal development in boars. Int. J. Andr., 1, 317-330.

FRITZ I. B., LOUIS B. G., TUNG P. S., DORRINGTON J., 1978. Action of hormones on Sertoli cells during maturation. Ann. Biol. anim. Bioch. Biophys., 18, 555-563.

HANSSON V., PURVIS K., RITZEN E. M., FRENCH F. S., 1978. Hormonal regulation of Sertoli cell function in the rat. Ann. Biol. anim. Bioch. Biophys., 18, 565-572.

HSUEH A. J. W., DUFAU M. L., CATT K. J., 1976. Regulation of luteinizing hormone receptors in testicular interstitial cells by gonadotropin. Biochem. biophys. Res. Comm., 72, 1145-1152.

JOHNSEN S. G., 1969. Two types of Sertoli celis in man. Acta endocr., 61, 111-116.

KOTITE N.J., NAYFEH S. N., FRENCH F. S., 1968. FSH and androgen regulation of Sertoli cell function in the immature rat. Biol. Reprod., 18, 65-73.

MARTINO C. De, MARCANTE M. L., FLORIDI A., CITRO G., BELLOCCI M., CANTAFORA A., NATALI P. G., 1977. Sertoli cells of adult rats in vitro. A. morphologic and functional study. Cell Tiss. Res., 176, 69-90. 
MEANS A. R., 1977. Mechanisms of action of tollicle stimulating hormone (FSH), 163-198. In JOHNSON A. D., GOMES W. R., The testis. Vol. IV. Acad. Press (New York).

MEANS A. R., FAKUNDING J. L., HUCKINS C., TINDALL D. J., VITALE R., 1976. Follicle stimulating hormone, the Sertoli cell and spermatogenesis. Recent Progr. Horm. Res., 32, 477-522.

MEYER R., POSALAKY Z., MCGINLEY D., 1978. Development of Sertoli cell junctions in vitro. A freeze-fracture study. In vitro, 14, 916-923.

MORAT M., 1977. L'action morphogène des hormones gonadotropes sur les cellules de Leydig du testicule de verrat. II. Effets de l'administration de gonadotropine chorionique après hypophysectomie action in vivo et en culture organotypique. Arch. Anat. micr. Morph. exper., 66, 181-205.

MORAT M., CHEVALIER M., DUFAUREJ.P., 1971. Cultures in vitro de fragments de testicules de pore : étude morphologique et histoenzymologique. C. R. Soc. Biol., 165, 1894-1898.

MURPHY H. D., 1965a. Sertoli cell stimulation following intratesticular injections of FSH in hypophysectomized rats. Proc. Soc. exp. Biol. Med. (N. Y.), 118, 1202-1205.

MURPHY H. D., 1965b. Intratesticular assay of follicle-stimulating hormone in hypophysectomized rats. Proc. Soc. exp. Biol. Med. (N. Y.), 120, 671-675.

SOLARI A. J., FRITZ I., 1978. The ultrastructure of immature Sertoli cells. Maturation like changes during culture and the maintenance of mitotic potentiality. Biol. Reprod., 18, 329-345.

STEINBERGER A., STEINBERGER E., 1977. The Sertoli cells, 371-399. In JOHNSON A. D., GOMES W. R., The testis, Vol. IV. Acad. Press (New York).

TUNG P. S., DORRINGTON J. H., FRITZ I. B., 1975a. Structural changes induced by follicle stimulating hormone or dibutyryl cyclic AMP on presumptive Sertoli cells in culture. Proc. nat. Acad. Sci. (Wash.), 72, 1838-1842.

TUNG P. S., FRITZ I. B., 1975b. FSH and dibutyryl cyclic AMP directed changes in ultrastructure and properties of cultured Sertoli cell enriched cultures comparison with cultured testicular peritubular cells, 495-508. In FRENCH F. S., HANSSON V., RITZEN E. M., NAYFEH S. N., Hormonal regulation of spermatogenesis, Plenum Press, New York.

VEYSSIERE G., BERGER M., JEAN-FAUCHER Ch., DE TURCKHEIM M., JEAN CI., 1975. Dosage radioimmunologique de la testostérone dans le plasma, les gonades et les surrénales de foetus en fin de gestation et de nouveau-nés, chez le lapin. Arch. infer. Physiol. Biochim., 83, 667-683.

WARTENBERG H., 1978. Human testicular development and the role of the mesonephros in the origin of a dual Sertoli cell system. Andrologia, 10, 1-21.

WEDDINGTON S. C., HANSSON V., RITZEN E. M., HAGENAS L., FRENCH F. S., NAYFEH S. N., 1975. Sertoli cell secretory function after hypophysectomy. Nature, 254, 145-146.

WROBEL K. H., DIERICHS R., 1975. Wachstum und Differenzierung der Sertolizellen im Schweine hoden während der postnatalen Ontogenese. Verh. Anat. Ges., 69, 723-724. 